УДК 371.3(378)

Дмитро Вітер, доктор філософських наук, старший науковий співробітник, Національний університет оборони України імені Івана Черняховського, м. Київ

ORCID ID 0000-0002-7330-1280

Володимир Оліферук, кандидат технічних наук, Національний університет оборони України імені Івана Черняховського, м. Київ

ORCID ID 0000-0002-0722-7561

DOI: $10.33099 / 2617-1775 / 2021-02 / 29-42$

\title{
КОНЦЕПЦІЯ РОЗВИТКУ СИСТЕМИ ВІЙСЬКОВОЇ ОСВІТИ УКРАЇ̈И
}

Розглянуто перспективи законодавчого та нормативно-правового регулювання процесу розвитку системи військової освіти в Украӥни. Обтрунтовано необхідність внесення змін у діючі нормативно-правові акти з урахуванням нових завдань і викликів, щео стоять перед Збройними Силами України, а також пріоритетів, визначених зовнішньополітичним курсом держави на євроатлантичну інтеграцію. Надано пропозищї щзодо формування нової концепиії розвитку систему військової освіти Украӥни, побудовану на стандартах та підходах, прийнятих у державах-членах НАТО.

Ключові слова: вища освіта; військова освіта; концепџія; підготовка; професійна військова освіта; система військової освіти.

Постановка проблеми. Сучасний розвиток Збройних Сил України (далі 3СУ), пов'язаний з необхідністю відстоювати територіальну цілісність держави у поєднанні з реалізацією стратегічного курсу на євроатлантичну інтеграцію, суттєво змінив пріоритети будівництва ЗСУ, поставивши нові завдання перед офіцерами та військовими фахівцями. Зміна форм і способів сучасної збройної боротьби, поступовий перехід ЗСУ на стандарти НАТО потребує суттєвих змін у системі освіти та підготовки офіцерів та військових фахівців. Урахування цих змін, а також потреб ЗСУ у нарощуванні оперативних спроможностей, вимагає перегляду основних положень, викладених в концепції військової освіти, затвердженої Постановою Кабінету Міністрів України № 1410 від 15 грудня 1997 "Про створення єдиної системи військової освіти” [6].

Метою статті $\epsilon$ висвітлення пропозицій до концепції розвитку системи військової освіти в Україні.

Методи дослідження. У статті використано систему загальнонаукових i спеціальних методів теоретичного та емпіричного дослідження (аналіз наукової літератури з досліджуваної проблеми, систематизація та узагальнення, логічнопорівняльний методи, системний підхід, контент-аналіз).

Виклад основного матеріалу. Система військової освіти (далі - ВО) має орієнтуватись на конкретні потреби і завдання функціональної сфери, забезпечувати постійне підвищення рівня професійної підготовки та кваліфікації військових фахівців ЗСУ, інших складових сил безпеки і оборони, що вимагає застосування нових підходів до формування змісту військової 
освіти з метою забезпечення досягнення високого рівня операційної сумісності, міжвідомчої взаємодії та координації під час планування і проведення спільних операцій на рівні об'єднаних штабів за стандартами та процедурами НАТО. 3 огляду на це, актуальним є розвиток професійної військової освіти на основі принципу професійного розвитку, який визначає загальну тенденцію професіоналізації військової освіти, що передбачає інтеграцію органів управління військовою освітою, мережі закладів військової освіти, діючих стандартів вищої освіти (професійних стандартів), рівнів та ступенів кваліфікації освіти (галузева рамка кваліфікацій), законодавчої та нормативноправової бази в єдиний комплекс професійної підготовки військових фахівців у системі ВО. Професіоналізація військової освіти здійснюється на основі розвитку системи професійної підготовки військових фахівців й залишається невід'ємною складовою системи ВО, яка потребує суттєвого вдосконалення 3 урахуванням змін в оперативному середовищі, загальних тенденцій розвитку системи національної та міжнародної безпеки, змін принципів та методів ведення збройної боротьби, нових вимог до якості професійної підготовки військових фахівців відповідно до стандартів країн-членів НАТО.

Концепція розвитку системи ВО (далі - Концепція) має враховувати сучасні принципи застосування ЗСУ, інших складових сил безпеки і оборони, стандарти у сфері розвитку військової освіти держав-членів НАТО й грунтуватись на положенні про військову освіту як інтегровану до державної системи освіти, яка функціонує на засадах єдиної законодавчої та нормативноправової бази, стандартах держав-членів НАТО й спрямована на забезпечення здобуття ступенів вищої освіти у вищих військових навчальних закладах (даліВВН3), військових навчальних підрозділах закладів вищої освіти (далі - ВНП ЗВО), закладів фахової перед вищої військової освіти (далі-ЗФПВО) та здобуття рівнів військової освіти (тактичного, оперативного, стратегічного) на курсах лідерства, підготовки, перепідготовки та підвищення кваліфікації військових фахівців.

Правовою основою розроблення Концепції є: Конституція, Закони України “Про національну безпеку України”, “Про військовий обов'язок та військову службу", "Про освіту", "Про вищу освіту" [1-5], інші законодавчі та нормативно-правові акти з питань безпеки і оборони України, що регулюють питання розвитку військової освіти [6-7].

Концепція має орієнтуватись на вирішення проблем, пов'язаних з низкою чинників, серед яких найбільш впливовими є:

прискорення темпів інтеграції України до НАТО, що передбачає імплементацію стандартів професійної військової освіти провідних країн-членів НАТО до національної системи ВО;

виконання військами (силами) завдань в умовах високої динаміки змін сучасних форм, методів і засобів ведення збройної боротьби;

відсутність міжвідомчої координації при підготовці фахівців з питань безпеки i оборони держави, здійснення їх підготовки поза межами єдиної системи військової освіти; 
невідповідність організаційно-штатних структур ВВНЗ, ВНП ЗВО та ЗФПВО, їх матеріально-технічної бази меті та змісту професійної військової освіти, вимогам нормативно-правових актів та державного замовлення на підготовку військових фахівців;

відсутність у ВВНЗ, ВНП ЗВО та ЗФПВО дієвої системи внутрішнього забезпечення якості освіти;

відсутність сучасних механізмів оцінки військової освіти у ВВНЗ, ВНП ЗВО тощо.

Основною проблемою, на розв'язання якої має бути спрямована Концепція, є нарощування оперативних спроможностей Міністерства оборони України (далі - МО України), ЗСУ, інших складових сил безпеки і оборони для виконання завдань оборонного планування, застосування ЗСУ, спільних дій у складі об'єднаних органів військового управління, сумісності із силами оборони держав-членів НАТО. Розв'язання цієї проблеми визначає i конкретизує мету Концепції - визначення напрямів розвитку військової освіти щодо забезпечення безперервного професійного розвитку військових фахівців упродовж військової кар'єри (службової діяльності).

Основними завданнями, яка забезпечують досягнення зазначеної мети, $\epsilon$ :

створення багаторівневої системи професійної військової освіти відповідно до стандартів НАТО, кращих вітчизняних та закордонних практик;

уточнення вимог до змісту військової освіти 3 метою набуття персоналом МО України, ЗСУ, інших складових сил оборони нових компетентностей, операційної сумісності на основі стандартів прийнятих у збройних силах держав-членів НАТО;

удосконалення нормативно-правового регулювання законодавства України з питань військової освіти;

приведення організаційно-штатних структур вищих військових навчальних закладів, військових навчальних підрозділів закладів вищої освіти та закладів фахової передвищої військової освіти, їх матеріально-технічної бази у відповідність до мети та змісту професійної військової освіти, вимог нормативно-правових актів та державного замовлення на підготовку військових фахівців;

забезпечення ефективного використання наявних ресурсів сектору оборони;

приведення рівня підготовленості науково-педагогічних (педагогічних) працівників, інструкторського складу до мети та змісту професійної військової освіти;

забезпечення якості професійної військової освіти.

Зважаючи на основні шляхи вирішення цих завдань, досягнення мети и розв'язання зазначеної вище проблеми підчас формування концептуальних положень щодо розвитку системи ВО доцільно звернутись до діючого законодавства і нормативно-правових актів, за яким система військової освіти являє собою сукупність складників освіти, рівнів і ступенів освіти, кваліфікацій, освітніх програм, стандартів освіти, ліцензійних умов, закладів військової освіти та інших суб'єктів освітньої діяльності, учасників освітнього 
процесу, органів управління у сфері військової освіти, а також нормативноправових актів, що регулюють відносини між ними. При цьому військова освіта являє собою єдину систему безперервного професійного розвитку, яка здійснюється на основі інтеграції вищої освіти (формальної) та професійної (неформальної) освіти, що включає:

допризовну підготовку молоді;

підготовку осіб за військово-технічними та військово-медичними спеціальностями;

військово-професійну підготовку осіб рядового, сержантського (старшинського) складу строкової військової служби та військової служби за контрактом;

підготовку осіб на посади сержантського (старшинського) складу військової служби за контрактом з одночасним здобуттям фахової передвищої або вищої освіти;

підготовку осіб на посади офіцерського складу, яка здійснюється на основі загальної середньої, професійної (професійно-технічної), фахової перед вищої чи вищої освіти для здобуття відповідних ступенів вищої освіти та рівнів військової освіти (тактичний, оперативний, стратегічний).

Допризовна підготовка передбачає здобуття особами первинних загальновійськових спеціальних компетентностей. Вона здійснюється у загальноосвітніх і професійно-технічних навчальних закладах (далі - ПТНЗ) має забезпечувати здобуття первинних знань із загальновійськових дисциплін 3 метою скорочення терміну становлення молоді як солдатів i матросів. Допризовна підготовка проводиться у загальноосвітніх і ПТНЗ за навчальним предметом “Захист Вітчизни”.

У військових (військово-морських, військово-спортивних) ліцеях, ліцеях із посиленою військово-фізичною підготовкою здійснюється здобуття юнаками i дівчатами (ліцеїстами) із 13 років освіти військового профілю одночасно зі здобуттям базової та/або профільної середньої освіти, проведення поглибленої допризовної та посиленої фізичної підготовки і виховання в ліцеїстів готовності до військової служби. У ліцеях здійснюється підготовка відповідно Державному стандарту загальної середньої освіти, стандарту спеціалізованої освіти військового спрямування, а також підготовка ліцеїстів для подальшого вступу до ВВНЗ, ВНП ЗВО і подальшого проходження військової служби.

Підготовка осіб (призовників) за військово-технічними та військовомедичними спеціальностями здійснюється в системі навчальних закладів Товариства сприяння обороні України та професійно-технічних навчальних закладах.

Підготовка 3 військово-технічних спеціальностей проводиться 3 особами, які навчаються у професійно-технічних та середніх медичних навчальних закладах за професіями, спорідненими 3 військово-обліковими спеціальностями - безпосередньо в цих закладах.

Військово-професійна підготовка осіб рядового, сержантського (старшинського) складу строкової військової служби та військової служби за контрактом, яка здійснюється на основі базової, профільної середньої, 
професійної (професійно-технічної) чи фахової передвищої освіти передбачає декілька варіантів. Зокрема, підготовка (перепідготовка) військовослужбовців для проходження військової служби за контрактом проводиться на посадах рядового складу - базова загальновійськова підготовка та фахова підготовка за визначеною ВОС у навчальних центрах та на спеціальних курсах підготовки у військових частинах $3 \mathrm{CУ}$; сержантського i старшинського складу багаторівнева підготовка у навчальних центрах та військових навчальних закладах Збройних Сил України, а також курсова підготовка перед призначенням на посаду у військових частинах.

Базова загальновійськова підготовка рядового складу призначена для набуття особами, прийнятими на військову службу, первинних знань, навичок i умінь, необхідних для виконання обов'язків військової служби, і проводиться у навчальних центрах.

Фахова підготовка призначена для підготовки громадян до військової служби за контрактом на посадах рядового складу за визначеною ВОС та проводиться на спеціальних курсах у військових частинах за місцем проходження військової служби або за окремими спеціальностями чи посадами в іншій військовій частині з військовослужбовцями, які призначені на посади за спеціальностями, за якими підготовка (перепідготовка) у навчальних центрах не здійснюється; у навчальних центрах.

Багаторівнева підготовка військовослужбовців для призначення на посади сержантського і старшинського складу (крім посад, що передбачають освітньо-професійний ступінь вищої освіти “молодший бакалавр", та штатних посад інструкторів) проводиться на курсах лідерства та на курсах фахової підготовки за визначеною ВОС.

Підготовка військових фахівців для проходження військової служби за контрактом на посадах сержантського (старшинського) складу здійснюється за освітньо-професійними програмами із здобуттям ступеня вищої освіти “молодший бакалавр” або освітньо-професійного ступеня “фаховий молодший бакалавр" та додатково за планом-програмою фахової підготовки (курс лідерства середнього рівня).

Військово-професійні компетентності сержантського (старшинського) складу формуються у процесі опанування переліку навчальних дисциплін військово-професійного спрямування.

Багаторівнева підготовка військовослужбовців для призначення на посади сержантського і старшинського складу (крім посад, що передбачають освітньопрофесійний ступінь вищої освіти “молодший бакалавр”, “фаховий молодший бакалавр" та штатних посад інструкторів) проводиться на курсах лідерства та на курсах фахової підготовки за визначеною військово-обліковими спеціальностями (далі - ВОС) за рівнями: базовий; середній; підвищений; вищий.

Підготовка за базовим рівнем здійснюється за відповідними програмами на курсах лідерства з подальшою підготовкою на курсах фахової підготовки у навчальних центрах на базі повної загальної середньої освіти або освітньокваліфікаційного рівня “кваліфікований робітник” за ВОС, що споріднені 3 
раніше набутими спеціальностями, для заміщення посад командирів відділень та їм рівних.

Підготовка за середнім рівнем здійснюється за відповідними програмами на курсах лідерства 3 подальшим навчанням на курсах фахової підготовки в навчальних центрах на базі повної загальної середньої освіти та отриманого базового рівня підготовки для заміщення посад головних сержантів взводів, командирів взводів, головних сержантів рот та їм рівних.

Підготовка за підвищеним рівнем здійснюється за відповідними програмами на курсах лідерства 3 подальшим навчанням на курсах фахової підготовки у військових навчальних закладах на базі повної загальної середньої освіти та отриманого середнього рівня підготовки для заміщення посад головних старшин батальйонів та їм рівних.

Підготовка вищого рівня здійснюється за відповідними програмами на курсах лідерства 3 подальшим навчанням на курсах фахової підготовки у військових навчальних закладах на базі вищої освіти та отриманого підвищеного рівня підготовки для заміщення посад головних старшин бригад (полків), їм рівних та вище.

Функціонування системи багаторівневої підготовки на посади сержантського та старшинського складу здійснюється згідно вимог відповідних наказів МО України та інших складових сил безпеки і оборони.

Підготовка осіб сержантського (старшинського) складу на основі повної загальної середньої, професійної (професійно-технічної) освіти, з одночасним здобуттям фахової передвищої освіти або вищої освіти здійснюється у ЗФПВО.

Фахова передвища військова освіта передбачає засвоєння освітньопрофесійної програми 3 військової підготовки 3 метою набуття комплексу професійних компетентностей, формування та розвитку індивідуальних здібностей особи і поглибленого оволодіння військовою спеціалізацією та здобувається на основі профільної середньої освіти.

Фахова передвища військова освіта передбачає військово-професійну підготовку осіб рядового, сержантського (старшинського) складу військової служби за контрактом, яка здійснюється за освітньо-професійними програмами фахової передвищої освіти.

Особа може здобувати фахову передвищу освіту на основі базової середньої освіти, профільної середньої освіти (незалежно від здобутого профілю), професійної (професійно-технічної) освіти, фахової передвищої освіти або вищої освіти. Особи, які здобувають фахову передвищу освіту на основі базової середньої освіти, зобов'язані одночасно виконати освітню програму профільної середньої освіти професійного спрямування.

Підготовка фахових молодших бакалаврів здійснюється за освітньопрофесійними програмами відповідно до галузей знань і спеціальностей, за якими здійснюється підготовка фахівців з вищою освітою.

Підготовка військових фахівців для проходження військової служби за контрактом на посадах осіб офіцерського складу здійснюється на основі повної загальної, середньої, професійної (професійно-технічної), фахової передвищої 
чи вищої освіти для здобуття відповідних ступенів вищої освіти та рівнів військової освіти.

Вища освіта осіб на посади офіцерського складу проводиться у ВВНЗ, ВНП ЗВО відповідно до стандартів вищої освіти та переліку галузей знань і спеціальностей за освітніми ступенями: “бакалавр", “магістр" (цивільний або військовий); за освітнім і водночас першим науковим ступенем "доктор філософії”; за другим науковим ступенем “доктор наук”.

Підготовка військових фахівців для проходження військової служби за контрактом на посадах осіб офіцерського складу передбачає обов'язкове здобуття рівнів військової освіти (тактичний, оперативний, стратегічний).

Ураховуючи це, в Концепції доцільно передбачити, що здобуття ступеня вищої освіти “бакалавр" (тактичний рівень військової освіти) здійснюється:

за освітньо-професійною програмою із здобуттям ступеня вищої освіти “бакалавр” відповідно до вимог стандартів вищої освіти відповідних спеціальностей та додатково за освітньою програмою фахової підготовки офіцерського складу (курси лідерства L1-A та L1-B);

за професійною програмою підготовки офіцера тактичного рівня та програмою фахової підготовки (курси лідерства L1-A та L1-B) за спеціальністю (спеціалізацією) на основі здобутого ступеня вищої освіти “бакалавр" у закладах вищої освіти;

за освітньо-професійними (освітньо-науковими) програмами із здобуттям ступеня вищої освіти “магістр".

Військово-професійні компетентності військового фахівця (офіцера тактичного рівня) формуються у процесі опанування переліку навчальних дисциплін військово-професійного спрямування (програми базової підготовки L- 1A), як військово-професійної складової освітньо-професійної програми, і $\epsilon$ однаковими для офіцерів тактичного рівня всіх спеціальностей підготовки, професійної програми підготовки офіцерів тактичного рівня та план-програми фахової підготовки офіцерського складу (курс лідерства офіцерського складу L1B).

Для військових фахівців за спеціальностями (спеціалізаціями) підготовки осіб офіцерського складу, які навчаються у ВНП ЗВО за схемою підготовки "курсант", здійснюється вивчення навчальних дисциплін військовопрофесійного спрямування при опануванні ступеня вищої освіти “магістр". Водночас, може здійснюватися підготовка за схемою "бакалавр-магістр" із залученням на навчання випускників зі ступенем вищої освіти - "бакалавр" у кількості, що відповідає потребам замовників з підготовки військових фахівців. Решта випускників направляється на офіцерські посади у війська (сили).

Підготовка осіб на посади офіцерського складу тактичного рівня з числа випускників цивільних закладів вищої освіти (далі - 3ВО), які мають ступінь вищої освіти не нижче “бакалавр” у відповідних галузях знань за спеціальностями, спорідненими з військовими, може здійснюватися шляхом їх допідготовки у ВВНЗ, ВНП ЗВО. Обсяг освітньої програми на основі ступеня вищої освіти “бакалавр”, для забезпечення військово-професійних компетентностей та військово-спеціальних компетентностей Професійного 
стандарту офіцера тактичного рівня за військово-обліковою спеціальністю, визначає ВВНЗ (ВНП ЗВО).

Здобуття ступеня вищої освіти “бакалавр” передбачає проходження базового курсу професійної підготовка L-1A та L-1B за певними спеціалізаціями.

Здобуття ступеня вищої освіти “магістр” (оперативний рівень військової освіти) в галузі знань "Воєнні науки, національна безпека, безпека державного кордону" за спеціальностями "Військове управління (за видами збройних сил)", "Озброєння та військова техніка", “Забезпечення військ (сил)" особами офіцерського складу здійснюється в магістратурі Національного університету оборони України імені Івана Черняховського (далі - НУОУ) та Національної академії національної гвардії з числа тих вступників, які обіймають відповідну посаду тактичного рівня (не нижче штатної категорії “майор" та їй рівних), здобули ступінь вищої освіти “бакалавр” та які в рамках професійної військової освіти пройшли підготовку на курсах L-2 та L-3, а також пройшли курси підвищення кваліфікації.

Здобуття ступеня вищої освіти "магістр" (стратегічний рівень військової освіти) в галузі знань "Воєнні науки, національна безпека, безпека державного кордону" за спеціальністю "Національна безпека (за окремими сферами та видами діяльності)" особами офіцерського складу може здійснюватися на основі закінчення ними курсу вищого керівного складу L-4 і відповідних курсів підвищення кваліфікації у НУОУ.

Особи офіцерського складу із ступенем вищої освіти "магістр" мають право вступати до ад’юнктури ВВНЗ для навчання щодо здобуття наукового ступеня “доктор філософії”.

Особи офіцерського складу з науковим ступенем “доктор філософії” (“кандидат наук”) мають право вступати до докторантури для навчання із здобуттям наукового ступеня "доктор наук".

Наведена вище структура системи ВО відображає формальну освіту, визначену законодавством України. Проте, існуюча тенденція щодо професіоналізації військової освіти в Україні, що обумовлена процесами євроатлантичної інтеграції, потребує урахування специфіки неформальної освіти, до якої згідно вітчизняному законодавству відноситься військова освіта. 3 огляду на це, доцільно у рамках Концепції визначити основні напрями розвитку професійної військової освіти.

Професійна військова освіта здобувається в системі професійної підготовки військових фахівців, яка представлена курсами лідерства, а також курсами перепідготовки та підвищення кваліфікації.

Відповідно до сучасних принципів побудови та розвитку системи ВО, представлених досвідом держав-членів НАТО, структура підготовки на курсах лідерства згідно рівням військової освіти отримує наступний вигляд:

тактичний рівень:

L-1A - Базовий курс професійної військової освіти;

На курси L-1A залучаються особи, які здобувають або здобули ступень “бакалавр" (“магістр”). 
L-1B - Фаховий курс професійної військової освіти (рота) (TLP - Troop Leading Process):

На курси залучаються особи, які здобули або здобувають ступінь вищої освіти “бакалавр" та плануються до призначення на посади офіцерського складу.

L-1C - Фаховий курс професійної військової освіти (рота) (TLP+MDMP Military Decision Making Process):

На курси залучаються офіцери, які зараховані до резерву кандидатів для просування по службі на посади у підрозділах ЗСУ за штатно-посадовою категорію “капітан”.

L-2 - Підготовка офіцерів на командно-штабних курсах за видовою належністю (батальйон, бригада) (MDMP):

На курси залучаються офіцери, які зараховані до резерву кандидатів для просування по службі на посади у військових частинах (підрозділах) ЗСУ за штатно-посадовою категорію не нижче "майор" та мають ступінь вищої освіти “бакалавр” і вище.

оперативний і стратегічний рівні:

L-3 - Курс офіцерів об'єднаних штабів оперативного рівня (JOPP - Joint Operation Planning Process).

На курси L-3 залучаються офіцери, які зараховані до резерву кандидатів для просування по службі на посади оперативного рівня за штатно-посадовою категорію не нижче “підполковник" та мають ступінь вищої освіти “бакалавр" і вище. Курси проводяться на базі НУОУ імені Івана Черняховського.

L-4 - Курс вищого керівного складу стратегічного рівня (JOPP).

На курси L-4 залучаються офіцери, які зараховані до резерву кандидатів для просування по службі на посади стратегічного рівня за штатно-посадовою категорію не нижче "полковник" та мають ступень вищої освіти "магістр (спеціаліст)" і вище. Курси проводяться на базі НУОУ імені Івана Черняховського.

L-5 - Курс стратегічного управління вищого рівня та державної політики.

На курси залучаються генерали та адмірали, які здобули ступінь вищої освіти "магістр" (за напрямом “державне воєнне управління") та стратегічний рівень військової освіти (Курс вищого керівного складу стратегічного рівня L- 4); керівники структурних підрозділів MOУ, ГШ ЗСУ, інших складових сил безпеки i оборони, центральних органів державної влади, до сфери відповідальності яких відносяться питання оборони та безпеки держави, які мають ступінь вищої освіти "магістр" (за напрямом “державне управління", "національна безпека"). Курси проводяться на базі НУОУ імені Івана Черняховського.

Підвищення кваліфікації передбачає виконання вимог професійних стандартів (формування військово-професійних і професійно-спеціальних компетентностей) i проводиться підчас виконання офіцерами службових обов'язків на посадах у військах (силах) за призначенням через систему проходження курсів за спеціалізаціями 3 видачею відомчого свідоцтва. 
Підвищення кваліфікації здійснюється на відповідних курсах, до яких в системі ВО відносяться:

Курси підвищення кваліфікації військовослужбовців та працівників ЗСУ, які проводяться на базі ВВНЗ на тактичному, оперативному і стратегічному рівнях військової освіти.

Курси перепідготовки та підвищення кваліфікації (допідготовки) офіцерів, прийнятих на військову службу за контрактом з запасу (за відповідними спеціалізаціями підготовки військових фахівців) тактичного рівня, які проводяться на базі ВВНЗ, ВНП ЗВО.

Курси підготовки та підвищення кваліфікації офіцерів багатонаціональних штабів, національного персоналу та керівного складу національних контингентів.

Курси підвищення кваліфікації науково-педагогічних та наукових працівників, які проводяться на базі ВВНЗ.

Курси підготовки та підвищення кваліфікації військовослужбовців військової служби за контрактом рядового та сержантського (старшинського) складу ЗСУ, які проводяться на базі ВВНЗ, ВНП ЗВО.

Концепція також має передбачати вирішення питань підготовки науковопедагогічних (педагогічних, наукових) працівників. Така підготовка має здійснюватись 3 урахуванням напрямів науково-педагогічної діяльності в ад’юнктурах (аспірантурах) та докторантурах на освітньо-науковому рівні “доктор філософії” та науковому рівні “доктор наук”. Водночас перепідготовка та підвищення кваліфікації науково-педагогічних (педагогічних, наукових) працівників має здійснюватись у системі післядипломної освіти, шляхом проходження курсів підвищення кваліфікації та стажування в Україні і за кордоном.

Іншим важливим напрямом забезпечення процесу розвитку системи ВО $\epsilon$ наукова діяльність. Наукова, науково-технічна та інноваційна діяльність у ВВНЗ, ВНП ЗВО та ЗФПВО є невід'ємною складовою освітньої діяльності й проводиться з метою інтеграції наукової, освітньої і професійної діяльності в системі військової освіти. Провадження наукової і науково-технічної діяльності у ВВНЗ, ВНП ЗВО та ЗФПВО є обов'язковим.

Представлені вище погляди на формування Концепції потребують конкретизації 3 огляду на основні шляхи і способи розв'язання проблеми професіоналізації військової освіти - розвитку системи професійної військової освіти. У цьому контексті до основних шляхів, які спрямовані на забезпечення процесу імплементації концептуальних принципів розвитку системи ВО, відносяться:

реалізація державної політики з питань національної безпеки у воєнній сфері, сферах оборони і будівництва у мирний час та особливий період;

реалізація державної політики у сфері військової освіти, науки і підготовки військових фахівців для ЗСУ, інших військових формувань;

удосконалення нормативно-правового забезпечення модернізації системи військової освіти з питань забезпечення якості освітньої діяльності та набуття повної взаємосумісності зі збройними силами держав-членів НАТО; 
впровадження стандартів НАТО в освітню діяльність та освітній процес ВВНЗ, ВНП ЗВО, ЗФПВО;

розроблення стандартів професійної військової освіти для кожної спеціальності з підготовки офіцерів та військових фахівців ЗСУ, інших складових сил безпеки і оборони з урахуванням стандартів НАТО;

розроблення та імплементація в освітній процес новітніх навчальних програм, зорієнтованих на підвищення рівня практичної підготовки до професійної діяльності за стандартами країн-членів НАТО та країн-партнерів;

удосконалення системи мотивації постійного та змінного складу ВВНЗ; ВНП ЗВО, ЗФПВО.

впровадження інноваційних педагогічних технологій в процес військової освіти офіцерів та військових фахівців, приведення рівня підготовленості науково-педагогічних (педагогічних) працівників, інструкторського складу до мети та змісту професійної військової освіти;

впровадження персональної відповідальності стейкхолдерів за провадження освітньої діяльності;

впровадження інституційного аудиту професійної військової освіти;

гармонізація положень концепції розвитку системи ВО 3 концепцією кадрової політики у ЗС України;

створення системи військово-патріотичного виховання молоді.

Безумовно, цей перелік не є вичерпним, але у сукупності наведені шляхи спрямовані на досягнення конкретних результатів, які можна очікувати від реалізації основних принципів концепції у майбутньому.

Очікуваними результатами реалізації Концепції:

забезпечення системою військової освіти набуття оперативних (бойових, спеціальних) спроможностей МО України, ЗСУ, інших складових сил безпеки та оборони;

впровадження та розвиток багаторівневої системи професійної військової освіти;

унормування системних перетворень професійної військової освіти шляхом набуття чинності змін до законів України та нормативно-правових актів;

забезпечення умов для кар'єрного зростання на основі здобуття відповідних ступенів вищої освіти та рівнів військової освіти;

забезпечення якості військової освіти;

приведення організаційно-штатних структур ВВНЗ, ВНП ЗВО та ЗФПВО, їх матеріально-технічної бази у відповідність до мети та змісту професійної військової освіти, вимог нормативно-правових актів та державного замовлення на підготовку персоналу;

уточнення підпорядкування ВВНЗ, ВНП ЗВО та ЗФПВО;

укомплектування ВВНЗ, ВНП ЗВО та ЗФПВО підготовленими науковопедагогічними (педагогічними) працівниками та інструкторським складом, у тому числі з країн-партнерів та держав-членів НАТО;

сертифікація професійної військової освіти за стандартами держав-членів НАТО та взаємне визнання документів про професійну військову освіту 
(сертифікатів), отриманих у ВВНЗ України та іноземних держав.

Висновки та перспективи подальших досліджень. Впровадження нової концепції військової освіти України сприятиме розвитку системи професійної військової освіти, гармонічному поєднанню формальної та неформальної освіти в межах єдиної (спільної) системи військової освіти, забезпечуючи необхідний рівень освіти та підготовки військових фахівців до виконання завдань, що ставить перед ЗСУ сучасність, створюючи можливості набуття оперативних спроможностей всіма складовими сил безпеки і оборони держави. Подальший розвиток нормативно-правового забезпечення пов'язаний 3 переходом до стандартів НАТО, що потребує розробки політик і доктрин як регуляторів процесів, цілей та спроможностей системи військової освіти України.

\section{ЛIТЕРАТУРА}

1. Закон України “Про вищу освіту” від 1 липня 2014 року № 1556-VII зі змінами. URL: www.rada.zakon.gov.ua.

2. Закон України “Про військовий обов'язок та військову службу” (редакція від 01.01.2021 № 2232-XII). - URL: www.rada.zakon.gov.ua.

3. Закон України “Про освіту” від 5 вересня 2017 року № 2145-VIII. - URL: www.rada.zakon.gov.ua.

4. Закон України "Про національну безпеку України” від 21 червня 2018 року № 2469VIII. - URL: www.rada.zakon.gov.ua.

5. Закон України “Про фахову передвищу освіту” від 6 червня 2019 року № 2745-VIII. URL: www.rada.zakon.gov.ua.

6. Постанова Кабінету Міністрів України № 1410 від 15 грудня 1997 року "Про створення єдиної системи військової освіти". - URL: www.rada.zakon.gov.ua.

7. Наказ МО України від 30.11.2020 №448 “Про організацію та проведення курсів професійної військової освіти та підвищення кваліфікації військовослужбовців та працівників Збройних Сил України у 2021-2022 роках". - URL: www.mil.gov.ua.

\section{REFERENCES}

1. Zakon Ukrainy "Pro vyschu osvitu”, 01.07.2014, № 1556-VII. - URL: www.rada.zakon.gov.ua.

2. Zakon Ukrainy "Pro viyskovyi oboviazok ta viyskovu sluzbu", 01.01.2021, № 2232-XII. URL: www.rada.zakon.gov.ua.

3. Zakon Ukrainy "Pro osvitu”, 05.09.2017, № 2145-VIII. - URL: www.rada.zakon.gov.ua.

4. Zakon Ukrainy "Pro natcionalnu bezpeku Ukrainy", 21.06.2018, № 2469-VIII. - URL: www.rada.zakon.gov.ua.

5. Zakon Ukrainy "Pro fahovu peredvyschu osvitu”, 06.06.2019, № 2745-VIII. - URL: www.rada.zakon.gov.ua.

6. Postanova Kabinetu Ministriv Ukrainy "Pro stvorennia edynoi systemy viyskovoi osvity", 15.12.1997, № 1410. - URL: www.rada.zakon.gov.ua.

7. Nakaz MO Ukrainy, 30.11.2020, №448 "Pro organizatciyu ta provedennya kursiv profesiynoi viyskovoi isvity ta pidvishenia kvalifikatcyi viyskovosluzbovciv ta pracivnykiv Zbroinyh Syl Ukrainy u 2021-2022 rokah. - URL: www.mil.gov.ua.

\section{РЕЗЮМЕ}

Дмитрий Витер, доктор философских наук, старший научный сотрудник, Национальный университет обороны Украины имени Ивана Черняховского, 
Владимир Олиферук, кандидат технических наук, Национальный университет обороны Украины имени Ивана Черняховского

\title{
Концепция развития системы военного образования Украины
}

\begin{abstract}
Рассмотрены перспективы законодательного и нормативно-правового регулирования прочесса развития системы военного образования в Украине. Обоснована необходимость внесения изменений в действующие нормативно-правовые акты с учетом новых задач и вызовов, которые стоят перед Вооруженными Силами Украины, а также приоритетов, определенных внешнеполитическим курсом государства на евроатлантическую интеграцию. Представлены предложения о формировании новой концееции развития системы военного образования Украины, построенной на стандартах и подходах, принятых в государствах-членах НАТО.
\end{abstract}

Ключевые слова: военное образование; высшее образование; концепция; подготовка; профессиональное военное образование; система военного образования.

\section{SUMMARY}

Dmitry Viter,
nior researcher,

National Defense University of Ukraine named after Ivan Cherniakhovskyi,

Oliferuk Volodymyr,

$\mathrm{PhD}$ (Technical sciences),

National Defense University of Ukraine named after Ivan Cherniakhovskyi

\section{Conception of the military education system's development in the Ukraine}

Introduction. Contemporary development of the Armed Forces of Ukraine connected with necessity to defend territorial wholeness of the state considering the realization of the strategic course to Euro-Atlantic integration, radically changed the priority of AF of Ukraine building, and based the new tasks before officers and military specialists. The change of forms and methods of warfighting, transit of AF of Ukraine to NATO's standards needing the making changes in the system of education and training of the officers and military specialists.

Purpose. The proposals for conception of the military education development in Ukraine represent.

Methods. The system of general scientific and special methods of theoretical and empirical research (analysis of scientific literature, systematization and generalization of materials, logic and comparative, content analysis) was used in order to realize the article purpose.

Results. The perspectives of law and normative regulation of the conception of the military education development process in Ukraine are considered. The necessity of making a changes to existing law and normative acts within a new tasks and callings that arises before Armed Forces of Ukraine, and priorities which determined by the foreign-political course of the state to Euro-Atlantic integration, argued. The proposals for forming the conception of the military education development in Ukraine that based on the standards and approaches which achieves in the state-members of NATO, represented.

Originality. The military education system must orient to concrete needs and tasks of functional sphere, ensuring the high level of professional training and qualification of military specialists in AF of Ukraine, other parts of safety and defense forces, that need using the new approaches for military education content forming with purpose of the achievement the high level 
of operational compatibility ensuring, interdepartmental interaction and coordination during the planning and making joint operations on the level of joint stabs according the standards and procedures of NATO.

The new conception of the military education development in Ukraine implementation will achieve the professional military education system development, the harmonic unite the formal and informal education in frame of the common (joint) system of military education that will ensuring need level of education and training of military specialists and officers for deciding the tasks which arising before AF of Ukraine in contemporary. That making abilities for acquisition the operational responsibilities by the all parts of the defense and defense forces of the state.

Conclusion. Implementation the new conception of military education of Ukraine will achieve the system of professional military education development, the harmonically unite the formal and unformal education in frame of common (joint) system of military education, that ensuring needed level of education and training of military specialists and officers for solving the tasks, which is call by today for AF of Ukraine. This process is making ability for acquisition of the operational responsibilities by the all parts of the safety and defense of state. In point of view the perspective of the law and normative ensuring the development connected with transit to NATO's standards that need making the politics and doctrines as regulators of process, purposes and responsibilities of the military education system in Ukraine.

Key words: conception; high education; military education; professional military education; system of military education; training. 